\title{
Employer Responses to Legislation Protecting Non-Regular Workers: Evidence from South Korea
}

\author{
HYEJIN KO* (D) AND ANDREW WEAVER** (iD) \\ ${ }^{*}$ Associate Research Fellow, Korea Institute for Health and Social Affairs \\ ${ }^{* *}$ Assistant Professor, School of Labor \& Employment Relations, University of Illinois at \\ Urbana-Champaign
}

\begin{abstract}
Many countries have taken steps to address employment insecurity by enacting employment protection legislation (EPL) for non-regular workers. Although the aggregate impacts of EPL reforms have been examined in the literature, less attention has been paid to the heterogeneous ways that different types of employers respond to these reforms. In this paper, we seek to shed additional light on the impact of non-regular workforce protections by investigating the response of establishments to legal changes in Korea in 2007. We employ a difference-indifference framework to explore which establishment characteristics predict that employers will convert non-regular workers to regular status. Results indicate that, in the short term, the Korean labor reforms led to increased conversions of fixed-term workers to permanent status. Establishments that have shifted risk onto workers via the use of performance pay are more likely to extend permanent status to non-regular workers. However, establishments that provide favorable employment conditions were less likely to convert. Unions play a double-edged role. Unions in large establishments with a wide range of occupational categories are associated with relatively greater conversion of outsiders to regular status, while unions in smaller, more resource-constrained establishments with a narrower occupational focus are associated with more exclusionary behavior.
\end{abstract}

Keywords: Employment Protection Legislation (EPL); Non-regular Workers; Fixedterm Workers; South Korea

\section{Introduction}

The issue of how to promote economic growth while protecting workers has been a constant source of debate and concern for policymakers over the past few decades. On the one hand, measures such as strict prohibitions on dismissals often discourage corporate hiring (Baek and Park, 2018; Heimberger, 2020; Millán et al., 2013; Piton, and Rycx, 2019). On the other hand, complete deregulation of labor market practices has the potential to lead to unstable employment and low equilibrium job quality (Gebel and Giesecke, 2016; Kahn, 2010; Litwin and Phan, 2013). In order to thread the needle between the worthy objectives of economic growth and job quality, policymakers need empirical evidence 
on the precise impact of specific policy changes. Past research on employment protection legislation (EPL) and other labor-market interventions has been quite useful in exploring aggregate employment effects, as well as in delineating how different types of capitalist economies - and their respective corporate sectors interact with labor-market regulations (Esping-Andersen, 1990; Mares, 2001). However, there has been little research that has investigated how particular labor market actors within a given economic system respond to these interventions. As Swenson (2004) has noted, the interests of the corporate sector are not monolithic. Likewise, disagreement exists over whether unions mainly protect insiders or whether they pursue more inclusive social goals (Durazzi, Fleckenstein and Lee, 2018; Lee, Kim and Cho, 2005). Furthermore, the fact that certain industries or unions support (or oppose) the initial passage of labor-market reforms does not tell us how individual employers or establishment-based unions will respond once the measures have been implemented. In particular, when legislation attempts to restrict the use of non-regular (fixed-term) workers, we have little idea of how different types of firms or unions respond to these policy shocks. Is there heterogeneity in the way that these labor-market actors react? Which entities respond positively to the legislation by upgrading non-regular workers to permanent positions? Conversely, which entities resist the spirit of the new laws by terminating these same workers?

This study attempts to shed light on the causal impact of EPL targeted at non-regular workers by utilizing a detailed establishment-level dataset from South Korea. To preview results, we find that conversion of fixed-term workers to regular status did increase after the implementation of the EPL, at least in the short-term. Notably, the establishments with higher profits were more likely to convert fixed-term workers in the short-term. Also, establishments that use a performance-based pay system, which implies shifting performance risk onto employees, were more likely to convert fixed-term workers in the short-term. However, organizations with the most desirable working conditions were significantly less likely to convert fixed-term workers. Unions play a double-edged role. Unions in large establishments with a wide range of occupational categories are associated with relatively greater conversion of outsiders to regular status, while unions in smaller, more resource-constrained establishments with a narrower occupational focus are associated with more exclusionary behavior. The findings imply that policymakers should design EPL and other labor market reforms with the anticipation that compliance may be lower not only among organizations that are resource-constrained, but also among establishments with relatively higher job quality and among small unionized establishments with limited occupational diversity.

This study is structured as follows: Section 2 introduces the policy background of Korean EPL. Section 3 discusses the macro-oriented literature on firms, unions, and social-welfare legislation, while Section 4 addresses the more 
human-resource-oriented literature on firm heterogeneity in a policy context. Section 5 presents hypotheses, while Section 6 reviews the empirical strategy used to identify the impact of Korean employment protection legislation at the establishment level. Section 7 presents results, and Section 8 concludes.

\section{Policy Background of Employment protection legislation in Korea}

The nature of the debate over EPL has evolved over time. In the 1990s, there was substantial pressure on countries with strong worker protections to liberalize their labor laws (Kahn, 2010; Organization for Economic Cooperation and Development [OECD], 2014). In East Asia, the 1997 financial crisis and the policies of the International Monetary Fund and other international actors intensified these pressures (Kwon, 2001; OECD, 2007). Some countries in Europe and Asia responded by relaxing laws and regulations that limited the use of temporary workers while maintaining protections for regular, "core" workers (Cooke and Jiang, 2017; Kwon and Holliday, 2007; Peng, 2012; Watanabe, 2018). While the impact of this liberalization varied by country (Avdagic, 2015; De Lange et al., 2014; Dolado et al., 2016; Gash, 2008), in general this particular combination of policies had the effect of increasing dualization of the labor market. That is, the proportion of temporary and peripheral workers increased substantially while a core of regular workers maintained their protected status. In Korea, the percentage of non-regular workers grew from $17 \%$ to $29 \%$ from 2001 to 2006 (Grubb et al., 2007).

In response to these dramatic increases in non-regular employment, a number of countries began to undertake a second set of reforms designed to reduce the dualization of the labor market (Eichhorst et al., 2017; OECD, 2013). The general idea of this subsequent set of policy interventions was to liberalize protections for regular workers while strengthening regulation of temporary and non-regular employment (OECD, 2013). In Korea, these efforts culminated in the 2007 employment reforms (Grubb et al., 2007). These regulations restricted the maximum length of fixed-term labor contracts and prohibited discrimination against non-regular workers in wages and various fringe benefits.

Evaluations of the impacts of such efforts to mitigate labor market duality have yielded mixed results, with effects varying by national context (Autor et al., 2006; Bentolila and Dolado, 1994; Dolado et al., 2002; Micco and Pagés, 2006). In Korea, research shows that the 2007 labor-market reforms had the effect of decreasing temporary jobs and increasing regular-status employment (Baek and Park, 2018; Yoo and Kang, 2012). In the near-term, total employment decreased; however, this negative effect appears to have faded out after two years (Yoo and Kang, 2012). What remains unclear, however, is the dynamics beneath these aggregate effects. To the extent that firms responded to these reforms, which 
firms converted non-regular workers to permanent status, and which firms simply shed temporary workers without granting access to permanent status?

\section{Firms, Unions, and Social Welfare Legislation}

Although traditional analyses of the development of social welfare programs often viewed capital and labor as homogenous forces with predictable orientations regarding social or labor-market interventions, in the past few decades scholars have introduced and tested much more nuanced models. The Varieties of Capitalism (VoC) literature has generally posited that the actions taken by both corporations and unions will vary based on the nature of the institutions and relationships that characterize a given country's economy (Esping-Andersen, 1990; Hall and Soskice, 2001). In these schemes, Korea was traditionally seen as a "corporatist" or "segmentalist" economy that relied heavily on large-firms and long-tenured employment (Cho, 2005; Jung and Cheon, 2006: 459-460). However, following the Asian financial crisis, Korea has introduced more liberal market elements to its economy and labor market (Cho, 2005; Lee and Shin, 2018; Witt and Jackson, 2016). Korean unions have also generally had a more fractious relationship with employers than other segmentalist nations such as Japan (Lee, C., 2006).

While these broad VoC models have done a great service in re-establishing firms as important actors in the development of a given labor-market regime, it is important to note that these models are best suited to making ex-ante, national-level predictions regarding the adoption of particular reforms or the development of particular institutions (Hall and Gingerich, 2009). Conditional on a given legislative or institutional reform being enacted, most of these models do not provide us with an ex-post prediction of which firms (or unions) within a given country's economic system will, in fact, cooperate in implementation. For this reason, in the current study we primarily focus on factors related to the firm-level heterogeneity that we contend is sometimes overlooked in the evaluation of EPL reforms (see below for discussion). However, despite the economy-wide focus of much of the VoC literature, we can test for the relative importance of two key factors that are relevant to VoC characterizations of the Korean economy: employer size and risk. With regard to the former, we can specifically investigate whether cooperation with the spirit of laws regulating the use of non-regular workers is concentrated in the larger establishments that are thought to be more involved in a corporatist embrace of labor-market interventions (Jung and Cheon, 2006). With regard to the latter, we can explore whether employers who bear more risk related to the performance of employees are more likely to convert non-regular workers to full-time status. We discuss both factors in more detail below. 
Beyond the firm-focused $\mathrm{VoC}$ literature, the industrial relations literature regarding unions provides another lens for thinking about employer responses to labor-market regulations. The role of unions in Korea's labor market has become a contested issue. One perspective holds that unions in Korea have generally promoted the interests of insiders while ignoring broader trends and policies that negatively affect other workers (Cho, 2005; Kim, 2006; Lee and Frenkel, 2004). However, some scholars have recently argued that Korean unions have actually behaved in a more socially oriented manner than they are given credit for (Durazzi et al., 2018, Fleckenstein and Lee, 2019). One intermediate argument has been that, to the extent that unions have pursued more narrow insider-oriented goals, they have not done so due to short-sighted preferences but rather due to factors relating to power differentials and the nature of the firms in which the unions are embedded (Kwon, 2015; Lee, Y., 2006; Peetz and Ollett, 2006). In our empirical analysis, we test for both union direct effects and for the possibility that union effects vary based on employer characteristics.

\section{The Implications of Firm Heterogeneity}

Most of the analysis of EPL has focused on aggregate outcomes and macro-level effects. However, we believe that it is essential to make a connection between policy and the responses of particular microeconomic actors. Doing so is particularly important to the extent that heterogeneity exists in the responses of various types of employers to policy changes. Although economic models used for policy analyses often treat all firms as fundamentally similar, there is growing evidence of considerable heterogeneity in adjustment to policy shocks (Dewit et al., 2019; Gal and Hijzen, 2016). Baek and Park (2018) show that, in the case of the 2007 Korean labor law reform, unionized establishments were more aggressive in seeking alternative forms of contingent employment that remained legal; however, the authors do not examine other sources of establishment-level heterogeneity. Understanding these sources of variation is clearly an important task for policymakers who wish to accurately anticipate the impact of various policy reforms.

Unfortunately, despite the relevance of this topic, data limitations have restricted the types of firm heterogeneity that researchers have been able to examine. A key point that is often overlooked in the literature is the possibility that firms may respond differently to legal or regulatory reforms based on differences in firm strategy or organizational characteristics. Regulatory or policy compliance is rarely a black-and-white matter; rather, pressures from policy changes interact with firm-level factors (and the institutional environment) to shape corporate responses (Kagan et al., 2003; Simpson et al., 2014). Evidence exists that these effects do show up when datasets enable appropriate measurement. For example, Hau et al. (2020) find that type of firm and 
associated management characteristics influences the degree to which firms substituted capital for labor in response to minimum wage increases in China. Borck and Coglianese (2011) likewise show that establishment characteristics (like plant age) and managerial attitudes/strategy predict the degree of compliance with environmental regulations. In this study, we will explore whether firms with various employment and organizational attributes are more or less likely to upgrade the jobs of non-regular workers following a legislative change.

\section{Hypotheses: Establishment Heterogeneity and Worker Conversion}

One heterogeneous factor that we would expect to influence conversion of nonregular workers to regular status is firm resources. In the face of a regulation that increases the cost of employing temporary workers, firms with greater industry rents - as measured by higher profitability - should be more willing to pay the costs of conversion rather than seek out alternative evasion mechanisms or redesign the production process (Abowd et al., 2012; Du Caju et al., 2009).

Hypothesis 1: Establishments with greater levels of profitability will be more likely to convert non-regular workers to permanent status.

Another factor that is related to firm resources is size. As noted above, many analysts have noted employer size (as measured by the number of employees) as a key feature of the Korean economy (Lee, Lee, and Lee, 2002; Jung and Cheon, 2006). Scholars have generally asserted that larger employers should be more willing to support labor-market regulations either because they have more organizational slack (Martin and Swank, 2012) or because they view such regulations as a means of suppressing competition from smaller, more resource-constrained employers (Swenson, 2004).

Hypothesis 2:. Larger establishments will be more likely to convert non-regular workers to permanent status.

The relative sharing of risk in the employment relationship is an additional - and complex - consideration. One influential strain of the VoC literature maintains that risk is positively associated with corporate support for labormarket interventions. Mares (2001) argues that firms facing greater levels of employment-related risks embrace social-welfare reforms in order to socialize these risks. However, it is worth noting that such a model, while perhaps well-suited to predicting whether firms in a given industry will support collective 
German-style apprenticeship programs, is less clear-cut with regard to other labor-market reforms. As Emmenegger (2014) has argued, job security regulations (which include restrictions on the use of temporary or non-regular workers) are conceptually different from other social policies, such as those involving government-subsidized training or unemployment insurance. The key difference is that job-security measures directly impinge on one of a firm's core operational activities: hiring and firing workers. This difference can yield very different predictions as it brings firm-level microeconomic strategy into play. A firm that has shifted employment risk from itself to its employees - say, by implementing pay systems contingent on performance - has lowered the downside risk associated with longer-term employment commitments. Because performance pay adjusts wages to individual productivity levels (Lemieux et al., 2009) while selectively encouraging applications from the most productive employees (Lazear, 1986, 2000, 2018; Lazear and Shaw, 2007), firms that rely on such systems should in theory be willing to extend full-time status to a wider range of potential workers. In this case, it would actually be the firm that faces less risk that is more supportive of a labor-market reform to limit the use of temporary employees. ${ }^{1}$ Based on the above discussion, we can hypothesize:

Hypothesis 3a: To the extent that employers are motivated by a strategic desire to socialize employment risks, establishments with performance pay systems will be less likely to convert non-regular workers to permanent status.

Hypothesis $\mathbf{3}$ b: To the extent that employers base their actions on the expected downside costs of permanently hiring potentially low-productivity employees, establishments with performance pay systems will be more likely to convert non-regular workers to permanent status.

The generosity of wages and benefits also likely affects firm decisions about worker conversions. Higher wages and benefits within the same industry - after controlling for potential rent-sharing (profits), size, and the presence of a union are signs of a different approach to the employment relationship. Firms that utilize high-performance work systems (HPWS) often adopt more generous compensation systems as part of a package of employment characteristics designed to maximize productivity (Ichniowski and Shaw, 1999; MacDuffie 1995). This package frequently includes highly structured internal labor markets (ILMs) which reward seniority, promote long-term job tenure, and limit hiring of outsiders to earlycareer employees via established recruitment channels (Cooke and Jiang, 2017; Horak and Yang, 2019; Jung, 1993; Knoke and Ishio, 1994; Osterman and Burton, 2004). While these systems have significant job-quality benefits for incumbent workers, their presence may limit the ability of non-traditional workers - such as non-regular workers seeking regular employment - to achieve 
permanent status. Although we have created the hypotheses below based on this logic of high-road employment systems, note that the presence of more generous employment conditions has implications for the balance of risk in the employment relationship. In the same way that performance pay reduces an employer's downside hiring risk, more expensive guaranteed pay and benefits increase the employer's risk from a bad hiring match.

Hypothesis 4a: Establishments with higher wages relative to similar firms in the same industry will be less likely to convert non-regular workers to permanent status.

Hypothesis 4b: Establishments with more generous fringe benefits will be less likely to convert non-regular workers to permanent status.

Finally, it is important to consider the role of unions. The impact of unions on worker conversions is theoretically ambiguous. On the one hand, many unions are primarily oriented toward serving the interests of permanent incumbent workers (Davidsson and Emmenegger, 2012; Lindbeck and Snower, 2001; Lee and Frenkel, 2004). From this perspective, unions might resist the extension of regular status to non-traditional workers either because such an extension requires sharing rents among a larger group, or because unions prefer to maintain some level of temporary workforce as a buffer against labor-market shocks (Bentolila and Dolado, 1994; Lee, Kim and Cho, 2005; Salvatori, 2009). On the other hand, many unions have goals that go beyond current-period monopolization of labor, including representing worker voice, increasing long-term bargaining power through recruitment, and promoting working-class policy goals (Durazzi et al., 2018; Fleckenstein and Lee, 2019; Freeman and Medoff, 1984; Heery, 2004, 2009). From this perspective, unions might push firms to convert non-regular workers to permanent status as the inclusion of these workers in the union could increase bargaining power, reduce social inequality, or otherwise strengthen the hand of labor in society.

It is also worth noting that union effects may not be monolithic. Unions might behave differently in different contexts. The scope of union action is likely constrained by the resources of the firm that the union is embedded within. Thus a union in a larger, more well-resourced firm - which already pays relatively higher wages - might be willing to embrace larger, strategic pro-labor goals, such as converting non-regular workers to permanent status and consequently limiting the growth of nonstandard work. By contrast, a union in a small, resource-constrained firm - which pays relatively lower wages - might feel that it needs to protect wages and benefits for existing members and thus to oppose the introduction of permanent status to outsiders who will increase competition for scarce resources (Kim and Lee, 2018; Kwon, 2015). 
Beyond the constraints associated with firm resources, unions may adopt heterogeneous strategies based on their own characteristics. As Oude Nijhuis (2009) argues, structure and membership are consequential for union strategy. "Horizontal" unions that represent one targeted (and perhaps privileged) group are more likely to narrowly protect insiders. By contrast, "vertical” unions that represent a variety of occupations - including those that are less well compensated - are more likely to embrace inclusionary policies and labor-oriented social goals (such as the conversion of non-regular workers to regular status).

Although there are a number of studies that investigate the relationship between unions and temporary staffing, there has been limited empirical evidence on the impact of unions on the conversion of non-regular workers to permanent status. Durazzi et al. (2018) provide qualitative evidence that Italian and Korean unions have in some cases been supportive of improvements in job quality for temporary workers. By contrast, Baek and Park (2018) find that the presence of unions in Korean firms was associated with greater use of contingent employment strategies in the wake of the 2007 reforms. Overall, the evidence on union responses to temporary workers shows examples of both inclusive and exclusive behavior (Kornelakis and Voskeritsian, 2018). Based on the above discussion, we can formulate the following hypotheses:

Hypothesis 5a: To the extent that unions are primarily focused on serving current-period incumbent workers, establishments with greater unionization will be less likely to convert non-regular workers to permanent status.

Hypothesis 5b: To the extent that unions pursue long-term growth strategies or broader social goals, establishments with greater unionization will be more likely to convert non-regular workers to permanent status.

Hypothesis 5c: Small establishments with greater unionization will be less likely to convert non-regular workers to permanent status, while large establishments with greater unionization will be more likely to convert.

Hypothesis $\mathbf{5 d :}$ Establishments with greater unionization and low occupational diversity will be less likely to convert non-regular workers to permanent status, while establishments with greater unionization and high occupational diversity will be more likely to convert.

\section{Empirical Strategy}

We utilize panel data on business establishments from the Workplace Panel Survey (WPS) to explore firm responses to employment protection. The WPS, which has been conducted every two years since 2005, provides a rich 
set of nationally representative variables on Korean business establishment characteristics during the period in which the non-regular worker protection reforms were adopted. It contains data on the sampled enterprise's employment structure, labor union status, and human resource management systems. We specifically investigate the impact of the 2007 reform limiting the duration of fixed-term labor contracts using WPS data from 2005 ( $1^{\text {st }}$ wave) to 2013 ( $5^{\text {th }}$ wave).

The intent of this legislation was to reduce the number of non-regular workers and encourage the creation of permanent labor contracts. Crucially, for our purposes, each survey contains establishment-level information on the number of non-regular workers who were employed at the time of the previous survey and who have converted to permanent status in the current period. We utilize the incidence of establishment conversion of non-regular workers to regular status as our focal dependent variable. Although there are other channels by which an employer could comply - for example, by creating new regular-status positions - conversion is an important phenomenon to investigate in order to understand the policy's impact. As a dependent variable, it has the advantage of involving the same worker pre- and post-reform, thus controlling for worker heterogeneity. Variation in conversion thus provides an important lens to examine differential compliance with labor-market reforms.

The main challenge to identifying the effect of Korea's non-regular worker protections is estimating counterfactual firm behavior in the absence of the reform. Although the reform limiting fixed-term contracts applied to all establishments in Korea, we can make use of the fact that not all business establishments were equally exposed to the legal change. Following Baek and Park (2018), we use an establishment's percentage of non-regular workers in 2005 (prior to the reform) as a measure of treatment intensity. The general idea is that establishments with a high percentage of non-regular, fixed-term contract workers will be heavily affected by the legal changes, while those with lesser levels will be less affected. We can then interact other establishment-level characteristics, such as the type of pre-reform wage contract or worker benefits, with the non-regular percentage measure to estimate how these characteristics affect the likelihood that an establishment will comply with the intent of the reform by converting non-regular workers to regular status.

Although it would be ideal to conduct a detailed pre-reform trend analysis to test for pre-trends, the fact that the WPS only contains one year of data prior to the reform precludes this approach. We follow Baek and Park (2018) in including industry-by-year and size-by-year fixed effects to flexibly control for major sources of group differences. The resulting specification thus estimates the causal impact of the reform using a triple difference-in-difference approach with variable treatment in both pre-reform non-regular worker percentage (Intensity) and establishment-level attributes (Characteristic): 


$$
\begin{aligned}
Y_{i}= & \alpha+\beta_{o} \text { Intensity }_{i}+\beta_{1} \text { After }_{t}+\beta_{2} \text { Characteristic }_{i} \\
& +\beta_{3} \text { Intensity }_{i} \times \text { After }_{t} \times \text { Characteristic }_{i}+\Phi X_{i}+\varepsilon_{i}
\end{aligned}
$$

The dependent variable $Y_{i}$ is a count of fixed-term contract workers within a given establishment who were converted to regular status. $X_{i}$ is a vector of labor-related establishment characteristics (see TABLE 1 for variable definitions and subsequent table notes for more details on specifications). After is a binary indicator for post-reform time periods (2009 and later years $=1$ ). We assume that fixed-term workers in 2007 did not renew or extend their fixed-term contracts after July 1, 2009, when the reform's restrictions took effect. ${ }^{2}$ Given that conversions are a non-negative count variable that exhibits overdispersion, we estimated all of our specifications with negative binomial regression models (including controls for employment size).

Descriptive statistics for the study sample are presented in TABLE 1. Across all establishments, about $10 \%$ of fixed-term workers were converted to regular status (Conversions divided by Exposure). TABLE 2 contains sample averages broken out by establishment's intensity of use of non-regular workers (fixedterm workers as a percentage of total employees). There are no significant differences between low and high-intensity establishments in the use of performance pay and profit level, but the proportion of firms with good wages, fringe benefits, and occupational diversity is higher in low-intensity firms. The proportion of large-sized companies, manufacturers, and unionized firms is also more prominent in low-intensity companies, and the proportion of unionized companies is also higher in low-intensity companies. We control for all these factors in our empirical specifications.

\section{Results}

We begin by presenting results on how establishment-level conversion of nonregular workers to permanent status varies by treatment intensity (that is, prior percentage of non-regular workers) in the absence of further organizational characteristics. TABLE 3 presents the marginal effects associated with this difference-in-difference exercise. The results indicate that establishments with higher proportions of non-regular workers engaged in significantly more conversions of these workers to permanent status. Specifically, employers that have a ten percentage-point higher proportion of fixed-term (non-regular) workers convert an additional 1.2 workers to regular status relative to establishments that were less exposed to the reform treatment (column (1) of TABLE 3). It is notable that we only detect a large and significant effect in the two years following the reform. Consistent with the Yoo and Kang (2012) findings on aggregate employment effects, the aggregate adjustment to reform via conversions appears to 
TABLE 1. Definition and Descriptive statistics of Variables

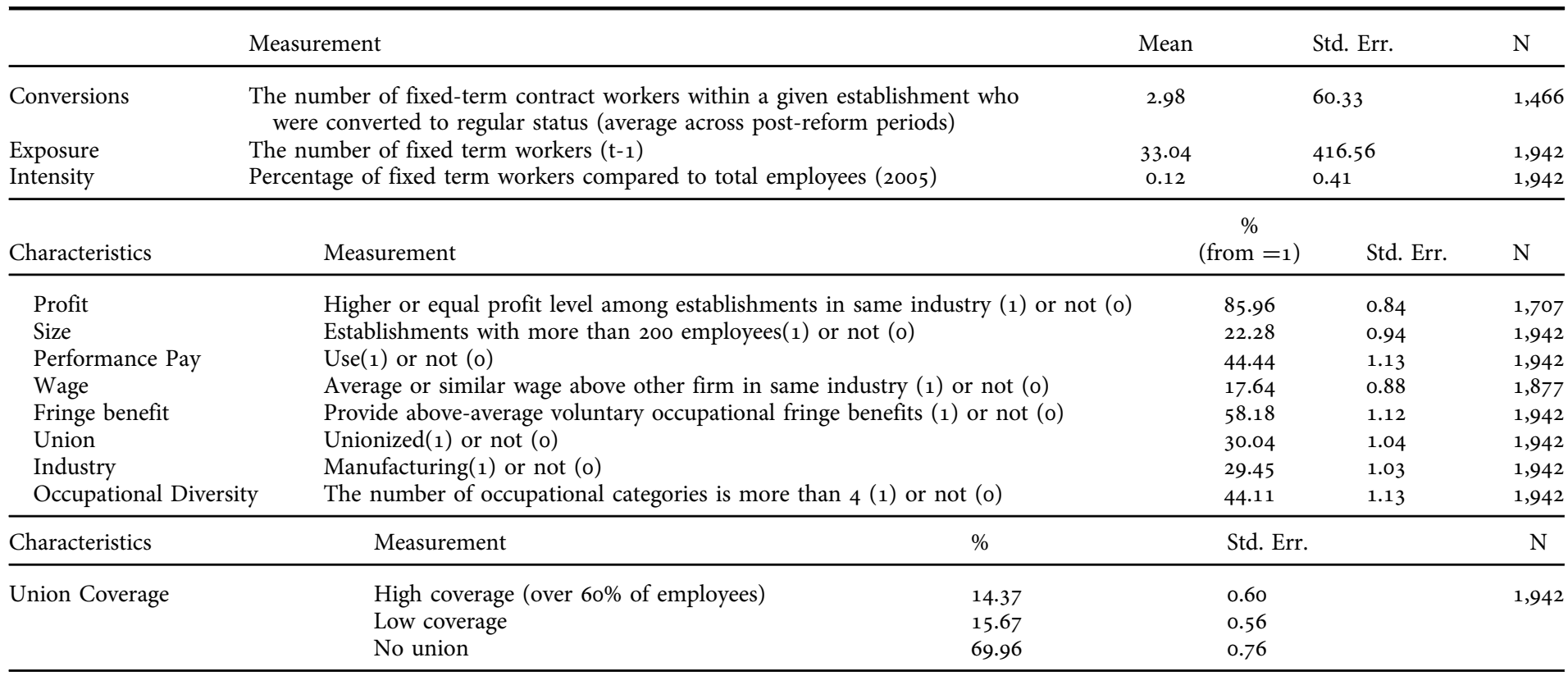

Note: Authors' calculation based on WPS data with longitudinal weights.

Source: Workplace Panel Survey (WPS), 2005-13. 
TABLE 2. Descriptive statistics of Variables by Intensity of Non-Regular Worker Employment

\begin{tabular}{|c|c|c|c|c|}
\hline Categories & \multicolumn{2}{|c|}{ Subcategories } & Mean & Std. Err. \\
\hline \multirow[t]{2}{*}{ Conversions } & \multirow{2}{*}{\multicolumn{2}{|c|}{$\begin{array}{l}\text { Low intensity } \\
\text { High intensity }\end{array}$}} & 2.29 & 90.12 \\
\hline & & High intensity & 3.87 & 77.96 \\
\hline \multirow[t]{2}{*}{ Exposure } & \multirow{2}{*}{\multicolumn{2}{|c|}{$\begin{array}{l}\text { Low intensity } \\
\text { High intensity }\end{array}$}} & 28.72 & 779.45 \\
\hline & & High intensity & $37 \cdot 37$ & 328.90 \\
\hline \multirow[t]{2}{*}{ Intensity } & \multirow{2}{*}{\multicolumn{2}{|c|}{$\begin{array}{l}\text { Low intensity } \\
\text { High intensity }\end{array}$}} & \multirow{2}{*}{$\begin{array}{l}0.01 \\
0.23\end{array}$} & 0.04 \\
\hline & & & & 0.63 \\
\hline Characteristics & \multicolumn{2}{|c|}{ Subcategories } & $\begin{array}{c}\% \\
(\text { from }=1)\end{array}$ & Std. Err. \\
\hline \multirow[t]{2}{*}{ Profit } & \multicolumn{2}{|c|}{ Low intensity } & 85.82 & 1.20 \\
\hline & \multicolumn{2}{|c|}{ High intensity } & 86.12 & 1.18 \\
\hline \multirow[t]{2}{*}{ Size } & \multicolumn{2}{|c|}{ Low intensity } & 26.07 & 1.44 \\
\hline & \multicolumn{2}{|c|}{ High intensity } & 18.49 & 1.22 \\
\hline \multirow[t]{2}{*}{ Performance Pay } & \multicolumn{2}{|c|}{ Low intensity } & 44.04 & 1.63 \\
\hline & High & nsity & 44.84 & 1.56 \\
\hline Wage & Low & sity & 18.34 & 1.28 \\
\hline & High & nsity & 16.91 & 1.21 \\
\hline Fringe benefit & Low & sity & 59.58 & 1.61 \\
\hline & High & nsity & 56.78 & 1.56 \\
\hline Union & Low & sity & 33.57 & 1.55 \\
\hline & High & nsity & 26.51 & 1.39 \\
\hline Industry & Low & sity & 42.56 & 1.62 \\
\hline & High & nsity & 16.35 & 1.16 \\
\hline Occupational Diversit & Low & sity & 47.40 & 1.64 \\
\hline & High & nsity & 40.82 & 1.54 \\
\hline Characteristics & Subcategories & & $\%$ & Std. Err. \\
\hline Union & ow intensity & High coverage & 18.10 & 0.86 \\
\hline Coverage & & Low coverage & 15.47 & 0.73 \\
\hline & & No union & 66.43 & 1.03 \\
\hline & High intensity & High coverage & 10.64 & 0.78 \\
\hline & & Low coverage & 15.87 & 0.88 \\
\hline & & No union & 73.49 & 1.10 \\
\hline
\end{tabular}

Note: Authors' calculation based on WPS data with longitudinal weights.

Source: Workplace Panel Survey (WPS), 2005-13.

primarily occur during the two years following implementation. We will now turn to our main specifications to explore the impact of organizational heterogeneity.

TABLE 4 presents the marginal effects from two sets of specifications for each time period (2007-09 and 2007-13). The Model-1 specifications only include one focal organizational characteristic. We control for the main effects of this characteristic and then interact it with After and Intensity (following equation (1)). This triple-difference represents the causal impact of a given prior 
TABLE 3. Conversion of Contract Workers to Permanent Status

\begin{tabular}{lcc}
\hline & from 2007 to 2009 & from 2007 to 2013 \\
\hline Difference in marginal effects & $12.336^{* *}$ & 2.472 \\
& $(5.764)$ & $(3.763)$ \\
$\mathrm{N}$ & 1,203 & 1,942 \\
(Pseudo) R2 & 0.008 & 0.005 \\
Log pseudo likelihood & -38238 & -71303 \\
\hline
\end{tabular}

Note: Specifications use negative binomial models with longitudinal weight. The number of fixed term workers from the previous survey year serves as the negative-binomial exposure variable. We use only cases that had one or more fixed contract worker in 2005. All models control for regional factors (regional GDP per capita and unemployment), establishment factors (industry, size), linear year trend, size-by-year and industry-by-year effects. TABLE figures are differences in marginal effects before and after treatment by non-regular worker intensity. Standard errors in parentheses are clustered at the establishment level and calculated based on the delta method.

${ }^{*} \mathrm{p}<0.1,{ }^{* *} \mathrm{p}<0.05,{ }^{* * *} \mathrm{p}<0.01$

establishment characteristic on worker conversions. The Model-2 specifications include the direct effects of all of the other organizational characteristics that are explored in TABLE 3 .

The results indicate that different types of establishments responded differently to the 2007 Korean labor law reform. Organizations that have performance pay systems - which shift the risk of a poor job match toward the employee - were significantly more likely to convert fixed-term workers to regular status in the two years following the implementation of the reform $\left(\mathrm{H}_{3} b\right.$ is supported; $\mathrm{H}_{3} \mathrm{a}$ is not supported). An establishment with a performance-pay system that has a ten percentage-point greater proportion of fixed-term workers converted an average of 2.4 more workers following the reform compared to a similar establishment prior to the reform ( $\mathrm{p}<0.01$; column (2) in TABLE 4). By the same token, organizations with signs of greater resources also appear more likely to convert workers in the near term. Establishments with higher profit levels than their industry peers and ten percentage-points more non-regular workers converted 2.2-2.3 more workers than similar establishments prior to the reform, depending on the specification $(\mathrm{p}<0.05$ without other covariates in column (1) of TABLE $4 ; \mathrm{p}<0.10$ in the full specification in column (2) in TABLE 4). $\mathrm{H}_{1}$ is thus modestly supported.

In contrast to these results, establishments with relatively more attractive employment conditions appear to have converted fewer workers. Organizations that pay higher wages and that have a ten-percentage point greater use of fixed-term workers converted 1.4-1.7 fewer workers in the two years following the reform, although the significance of the marginal difference drops to the 90 percent level in the full specification in column (2) ( $\mathrm{H}_{4} \mathrm{a}$ is modestly supported in the short run). Establishments with greater fringe benefits 
TABLE 4. Impact of Establishment Characteristics on Conversion of Fixed-Term Workers to Regular Status

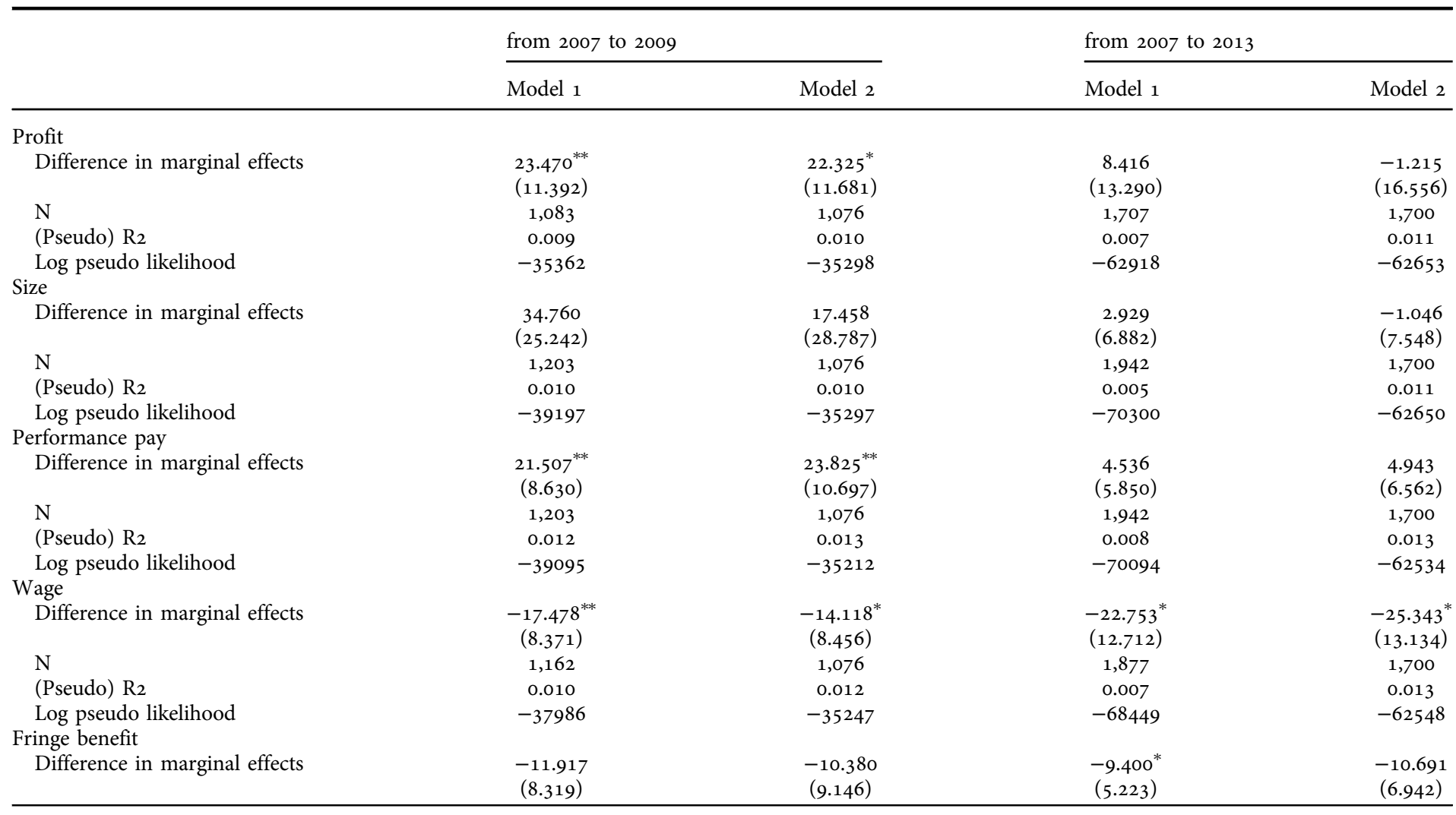




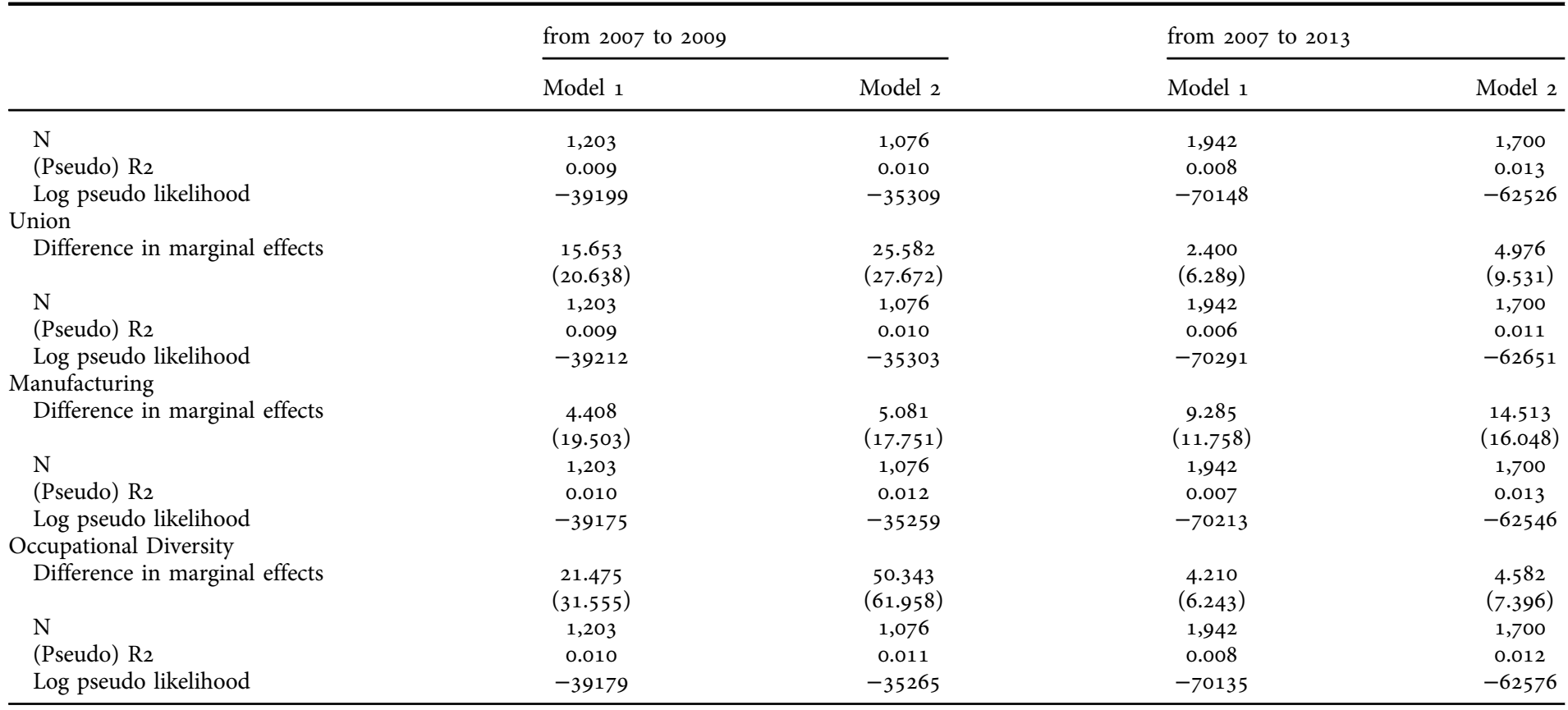

Note: Specifications use negative binomial models with longitudinal weight. The number of fixed term workers from the previous survey year serves as the negative-binomial exposure variable. We use only cases that had one or more fixed contract worker in 2005. All models control for regional factors (regional GDP per capita and unemployment), establishment factors (industry, size), linear year trend, size-by-year and industry-by-year effects. Model 2 includes all establishment factors simultaneously: performance pay, profit, wage, fringe benefit, union status, and occupational diversity. TABLE figures are differences in marginal effects before and after treatment by non-regular worker intensity and establishment characteristics. Standard errors in parentheses are clustered at the establishment level and calculated based on the delta method.

${ }^{*} \mathrm{p}<0.1,{ }^{* *} \mathrm{p}<0.05,{ }^{* * *} \mathrm{p}<0.01$ 


\begin{tabular}{|c|c|c|c|c|c|}
\hline & & \multicolumn{2}{|c|}{ from 2007 to 2009} & \multicolumn{2}{|c|}{ from 2007 to 2013} \\
\hline & & Model 1 & Model 2 & Model 1 & Model 2 \\
\hline \multicolumn{6}{|c|}{$\begin{array}{l}\text { Size and Union coverage } \\
\text { Difference in marginal effects }\end{array}$} \\
\hline Bigger & [high coverage-no union] (A) & $\begin{array}{c}86.671 \\
(180.757)\end{array}$ & $\begin{array}{l}122.879 \\
(190.612)\end{array}$ & $\begin{array}{l}23.949 \\
(29.474)\end{array}$ & $\begin{array}{l}19.603 \\
(24.052)\end{array}$ \\
\hline \multirow[t]{5}{*}{ Smaller } & [high coverage-no union] (B) & $\begin{array}{l}-48.221 * * * \\
(17.141)\end{array}$ & $\begin{array}{l}-61.624^{* *} \\
(24.579)\end{array}$ & $\begin{array}{l}-53.094^{* * *} \\
(18.936)\end{array}$ & $\begin{array}{l}-55.058^{* *} \\
(22.336)\end{array}$ \\
\hline & (A)-(B) & $\begin{array}{c}134.892 \\
(181.704)\end{array}$ & $\begin{array}{c}184.502 \\
(192.377)\end{array}$ & $\begin{array}{l}77.043^{* *} \\
(34.979)\end{array}$ & $\begin{array}{l}74.661^{* *} \\
(32.351)\end{array}$ \\
\hline & $\mathrm{N}$ & 1,203 & 1,076 & 1,942 & 1,700 \\
\hline & (Pseudo) $\mathrm{R}_{2}$ & 0.015 & 0.017 & 0.010 & 0.017 \\
\hline & Log pseudo likelihood & -38981 & -35051 & -69979 & -62293 \\
\hline \multicolumn{6}{|c|}{$\begin{array}{l}\text { Occupational Diversity and Union coverage } \\
\text { Difference in marginal effects }\end{array}$} \\
\hline More diversity & [high coverage-no union] (A) & $\begin{array}{c}84.214 \\
(114.150)\end{array}$ & $\begin{array}{c}57.792 \\
(82.119)\end{array}$ & $\begin{array}{c}3.646 \\
(24.563)\end{array}$ & $\begin{array}{c}-4.088 \\
(25.752)\end{array}$ \\
\hline \multirow[t]{5}{*}{ Less diversity } & [high coverage-no union] (B) & $\begin{array}{c}-41.781^{* * *} \\
(14.885)\end{array}$ & $\begin{array}{c}-38.508^{* *} \\
(18.161)\end{array}$ & $\begin{array}{c}-43.057^{* * *} \\
(13.881)\end{array}$ & $\begin{array}{c}-43.312^{* *} \\
(17.036)\end{array}$ \\
\hline & $(\mathrm{A})-(\mathrm{B})$ & $\begin{array}{c}125.995 \\
(114.868)\end{array}$ & $\begin{array}{c}96.301 \\
(83.932)\end{array}$ & $\begin{array}{l}46.703^{*} \\
(27.575)\end{array}$ & $\begin{array}{c}39.224 \\
(29.948)\end{array}$ \\
\hline & $\mathrm{N}$ & 1,203 & 1,076 & 1,942 & 1,700 \\
\hline & (Pseudo) R2 & 0.015 & 0.016 & 0.012 & 0.017 \\
\hline & Log pseudo likelihood & -38992 & -35105 & -69826 & -62280 \\
\hline
\end{tabular}

Note: Specifications use negative binomial models with longitudinal weight. The number of fixed term workers from the previous survey year serves as the negative-binomial exposure variable. We use only cases that had one or more fixed contract worker in 2005. All models control for regional factors (regional GDP per capita and unemployment), establishment factors (industry, size), linear year trend, size-by-year and industry-by-year effects. Model 2 includes all establishment factors simultaneously: performance pay, profit, wage, fringe benefit, union status and occupational diversity. TABLE figures are differences in marginal effects before and after treatment by non-regular worker intensity and establishment characteristics. Standard errors in parentheses are clustered at the establishment level and calculated based on the delta method.

${ }^{*} \mathrm{p}<0.1,{ }^{* *} \mathrm{p}<0.05,{ }^{* * *} \mathrm{p}<0.01$ 
show a similar pattern, although the near-term effects are not significant. Interestingly, organizations with more generous benefits show a marginally significant $(\mathrm{p}<0.10)$ reduction in conversions in the parsimonious long-term specification (column (3) in TABLE $4 ; \mathrm{H}_{4} \mathrm{~b}$ is weakly supported in the long run). Over the six years following the reform, higher-benefit establishments that had a ten percentage-point greater utilization of non-regular workers converted 0.9 fewer workers. It may be that firms find it more difficult to alter benefit structures than wages, thus extending the window of adjustment for high-benefit organizations.

The other specifications do not measure the benefit effect with precision, but the overall pattern of results is notable. Resources and risk-shifting are associated with more conversions, while better employment conditions are associated with fewer such occurrences. It is also worth stressing the fact that profits and wages have marginal effects that are of opposite sign. Generosity of employment conditions is a distinct phenomenon from organizational resources or access to industry rents, and it carries different implications for organizational responses to labor-market reforms. It is also worth noting that effects associated with employer size - a factor often stressed in analyses of the Korean labor market - are all insignificant ( $\mathrm{H}_{2}$ is not supported). ${ }^{3}$ As we will see in the following discussion, some of these null effects may be the result of underlying heterogeneity.

The final factor that we consider is the presence of a union. The results indicate that union status is positively correlated with worker conversions, but none of the effects are significant ( $\mathrm{H}_{5} \mathrm{a}$ and $\mathrm{H}_{5} \mathrm{~b}$ are not supported). Thus, unlike Baek and Park (2018), we do not find a significant union effect in the presence of controls for other organizational characteristics. However, as noted above, it could be that significant heterogeneous effects lie beneath the insignificant central tendency. Indeed, this is what we find when we further explore the interaction of the union effect with establishment size and occupational diversity (TABLE 5).

Consistent with $\mathrm{H}_{5} \mathrm{c}$, high-coverage unions in small establishments are associated with a lower likelihood of conversion, while high-coverage unions in large establishments are associated with a greater likelihood. The small-establishment union effects are consistently and significantly negative $(\mathrm{p}<0.05$ in the full short-term model, column (2) of TABLE 5), and the difference between the union-size effects is significant for the long-run models $(\mathrm{p}<0.05$, columns (3) and (4) of TABLE 5). $\mathrm{H}_{5} \mathrm{~d}$ is also supported. The combination of high union coverage with high occupational diversity predicts more conversions, while the combination of high union coverage with low occupational diversity predicts fewer conversions. The low-occupational-diversity union effects are consistently negative and significant ( $\mathrm{p}<0.05$ in the full short-term model, column (2) of TABLE 5), and the difference between the high and low effects is marginally 
significant in the parsimonious long-term model $(\mathrm{p}<0.10$, column (3) of TABLE 5). These results imply that whether unions promote the protection of insiders or broader social goals depends to some extent on host firm resources and on the occupational diversity of union membership.

\section{Discussion and Conclusion}

Organizational heterogeneity in response to policy changes is an important but often neglected topic. In this study we explore how establishments with differing characteristics responded to the 2007 Korean labor law reform limiting the usage of non-regular workers. The results indicate that organizations with the most desirable working conditions are less likely to convert fixed-term workers, while those that shift risk onto employees or have access to greater resources are more likely to extend regular status to existing non-regular employees. The implication is that firms that bear greater costs from the risk of a low-productivity hire, or those with employment systems whose logic is based on privileging incumbent workers, tend to be more resistant to offering permanent status to outsiders. Although some Varieties-of-Capitalism researchers find that industries that bear greater employment-related risks are more likely to support government labor-market interventions, our results indicate that, at the establishment level, the presence of greater employer-side risk is associated with resistance to the spirit of employment-protection legislation.

We also explored other factors relating to the Varieties-of-Capitalism literature and industrial relations systems. Employer size and the presence of a union have insignificant main effects, but this general result masks underlying heterogeneity. Unions in small establishments or that represent a narrow range of occupations exhibit behavior that is consistent with the protection of insiders (fewer conversions). By contrast, extension of permanent status to non-regular workers is relatively more likely when unions are present in large establishments or the unions have substantial occupational diversity. These results indicate that union influence on employer responses to employment-protection legislation is not monolithic, but rather varies with organizational structure and context.

It is important to acknowledge that these findings have limitations that point toward areas for future research. In this study we focus our attention on the conversion of fixed-term workers to permanent status. Although this phenomenon is the most direct measure of employer behavior regarding non-regular workers - particularly given the unique ability of our Korean dataset to track conversion of existing workers across time - there are obviously other corporate responses to the regulation of non-standard work that are relevant and worthy of investigation. It is also the case that the modest sample size of the WPS dataset limits precision. Although the patterns of effects are quite consistent, some key results are only marginally significant. It will be important 
in the future to test these results with larger samples and a variety of research designs.

Caveats aside, these findings have implications for policymakers who seek to improve job quality via employment protection legislation. Policymakers should be aware that reforms limiting reliance on non-regular workers do appear to open up permanent job opportunities for some workers, but these opportunities are not evenly distributed among all types of organizations. Legislative protections for non-regular workers are less likely to crack open access to firms with the most desirable jobs. Resource-constrained firms and small unionized employers with limited occupational diversity are also less likely to comply. These conclusions do not necessarily indicate that such reforms are ineffective. Rather, by understanding the heterogeneous nature of organizational responses to reform, analysts and policymakers can more accurately predict the impact of a given labor-market intervention and perform a more precise evaluation of its benefits and costs.

\section{Acknowledgements}

We are really grateful for the valuable feedback received at the 6th Annual Conference of the East Asian Social Policy Research Network (Taipei, Taiwan). This work was supported by the Ministry of Education of the Republic of Korea and the National Research Foundation of Korea (NRF-2018S1A5A8026972).

\section{Competing interests}

The author(s) declare none.

\section{Notes}

1 The use of performance pay in Korea increased substantially following the Asian financial crisis (Chang, 2006). On average, about $44 \%$ of establishments in our data report using the practice (Table 1). It is worth stressing that this practice is not limited to top executives: $90 \%$ of establishments that implement performance pay report extending the practice to all of their workers and $97 \%$ to at least half of their workers (authors' calculation based on WPS data, 2005-13).

2 The 2007 Korean reform applied to private establishments with 300 or more regular workers starting July 1, 2007; to establishments with more than 100 regular workers on July 1, 2008; and to establishments with five or more regular workers starting July 1, 2009.

3 The results are qualitatively similar when using an indicator for whether an establishment is part of a larger multi-site firm instead of using establishment employment size.

\section{References}

Abowd, J. M., Kramarz, F., Lengermann, P., McKinney, K. L. and Roux, S. (2012), 'Persistent inter-industry wage differences: rent sharing and opportunity costs', IZA Journal of Labor Economics, 1, 1, 1-25. 
Autor, D. H., Donohue III, J. J. and Schwab, S. J. (2006), 'The costs of wrongful-discharge laws', The review of economics and statistics, $88,2,211-231$.

Avdagic, S. (2015), 'Does deregulation work? Reassessing the unemployment effects of employment protection', British Journal of Industrial Relations, 53, 1, 6-26.

Baek, J. and Park, W. (2018), 'Firms' adjustments to employment protection legislation: Evidence from South Korea', Industrial and Labor Relations Review, 71, 3, 733-759.

Bentolila, S. and Dolado, J. J. (1994), 'Labour flexibility and wages: lessons from Spain', Economic policy, 9, 18, 55-99.

Borck, J. C. and Coglianese, C. (2011), 'Beyond compliance: explaining business participation in voluntary environmental programs', in C. Parker and V. L. Nielsen (eds.), Explaining Compliance: business responses to regulation, Cheltenham and Northampton: Edward Elgar Publishing, 139-141.

Chang, E. (2006), 'Individual Pay for Performance and Commitment HR Practices in South Korea'. Journal of World Business, 41, 4, 368-381.

Cho, H. (2005), 'Industrial Relations and Union Politics in Large Firms in South Korea'. in C. Lee and S. Kuruvilla (eds.), The Transformation of Industrial Relations in Large-size Enterprises in Korea: Appraisals of Korean Enterprise Unionism, Seoul: Korea Labor Institute, 83-130.

Cooke, F. L. and Jiang, Y. (2017), 'The growth of non-standard employment in Japan and South Korea: the role of institutional actors and impact on workers and the labour market', Asia Pacific Journal of Human Resources, 55, 2, 155-176.

Davidsson, J. B. and Emmenegger, P. (2012), 'Insider-outsider dynamics and the reform of job security legislation', in G. Bonoli, and D. Natali (eds.), The politics of the new welfare state, Oxford: Oxford University Press, 206-229.

De Lange, M., Gesthuizen, M. and Wolbers, M. H. (2014), 'Youth labour market integration across Europe: The impact of cyclical, structural, and institutional characteristics', European Societies, 16, 2, 194-212.

Dewit, G., Görg, H. and Temouri, Y. (2019), 'Employment protection and firm relocation: Theory and evidence', Economica, 86, 344, 663-688.

Dolado, J. J., García-Serrano, C. and Jimeno, J. F. (2002), 'Drawing lessons from the boom of temporary jobs in Spain'. The Economic Journal, 112, 480, F270-F295.

Dolado, J. J., Ortigueira, S. and Stucchi, R. (2016), 'Does dual employment protection affect TFP? Evidence from Spanish manufacturing firms', SERIEs, 7, 4, 421-459.

Du Caju, P., Ryckx, P. and Tojerow, I. (2009), 'Inter-Industry Wage Differentials: How Much Does Rent Sharing Matter?' National Bank of Belgium Working Paper, No. 180.

Durazzi, N., Fleckenstein, T. and Lee, S. C. (2018), 'Social solidarity for all Trade union strategies, labor market dualization, and the welfare state in Italy and South Korea'. Politics \& Society, 46, 2, 205-233.

Eichhorst, W., Marx, P. and Wehner, C. (2017), 'Labor market reforms in Europe: towards more flexicure labor markets?', Journal for labour market research, 51, 1, 1-17.

Emmenegger, P. (2014), The power to dismiss: Trade unions and the regulation of job security in Western Europe. Oxford: Oxford university Press, USA.

Esping-Andersen, G. (1990), The three worlds of welfare capitalism. Princeton: Princeton University Press.

Fleckenstein, T. and Lee, S. C. (2019), 'Organised labour, dualisation and labour market reform: Korean trade union strategies in economic and social crisis', Journal of Contemporary Asia, 49, 3, 452-472.

Freeman, R. B. and Medoff, J. L. (1984), What Do Unions Do? New York: Basic Books.

Gal, P. N. and Hijzen, A. (2016), 'The short-term impact of product market reforms: A crosscountry firm-level analysis', IMF Working Papers, Washington, D.C.: International Monetary Fund.

Gash, V. (2008), "Bridge or Trap? Temporary Workers' Transitions to Unemployment and to the Standard Employment Contract', European Sociological Review, 24, 5, 651-668. 
Gebel, M. and Giesecke, J. (2016), 'Does deregulation help? The impact of employment protection reforms on youths' unemployment and temporary employment risks in Europe', European Sociological Review, 32, 4, 486-500.

Grubb, D., Lee, J. and Tergeist, P. (2007), 'Addressing Labour Market Duality in Korea', OECD Social, Employment and Migration Working Papers, No. 61, Paris: OECD Publishing.

Hall, P. A. and Gingerich, D. W. (2009), 'Varieties of capitalism and institutional complementarities in the political economy: An empirical analysis'. British journal of political science, $39,3,449-482$.

Hall, P. A. and Soskice, D. (eds.) (2001), Varieties of capitalism: The institutional foundations of comparative advantage. New York: Oxford University Press.

Hau, H., Huang, Y. and Wang, G. (2020), 'Firm response to competitive shocks: Evidence from China's minimum wage policy', The Review of Economic Studies, 87, 6, 2639-2671

Heery, E. (2004), 'The trade union response to agency labour in Britain', Industrial Relations Journal, 35, 5, 434-450.

Heery, E. (2009), 'Trade unions and contingent labour: scale and method. Cambridge Journal of Regions, Economy and Society, 2, 3, 429-442.

Heimberger, P. (2020), 'Does Employment Protection Affect Unemployment? A Meta-analysis (No. 176)', The Vienna Institute for International Economic Studies, Working paper 176, https://wiiw.ac.at/does-employment-protection-affect-unemployment-a-meta-analysisdlp-5225.pdf [accessed 04.12.2020].

Horak, S. and Yang, I. (2019), 'Whither seniority? Career progression and performance orientation in South Korea', The International Journal of Human Resource Management, 30, 9, $1419-1447$.

Ichniowski, C. and Shaw, K. (1999), 'The Effects of Human Resource Management Systems on Economic Performance: An International Comparison of U.S. and Japanese Plants', Management Science, 45, 5, 704-721.

Jung, E. and Cheon, B. Y. (2006), 'Economic crisis and changes in employment relations in Japan and Korea'. Asian Survey, 46, 3, 457-476.

Jung, E. H. (1993), 'The Rise of the Labor Movement and the Development of Internal Labor Market in the Korean Manufacturing Industry'. Korea Journal of Population and Development, 22, 1, 23-41.

Kagan, R. A., Gunningham, N. and Thornton, D. (2003), 'Explaining corporate environmental performance: how does regulation matter?', Law and Society Review, 37, 1, 51-90.

Kahn, L. M. (2010), 'Employment protection reforms, employment and the incidence of temporary jobs in Europe: 1996-2001', Labour Economics, 17, 1, 1-15.

Kim, D. I. (2006), 'Korea's Unionism and Its Labor Market Outcomes', in C. Lee and S. Kuruvilla (eds.), The Transformation of Industrial Relations in Large-size Enterprises in Korea: Appraisals of Korean Enterprise Unionism, Seoul: Korea Labor Institute, 37-82.

Kim, H. T. and Lee, Y. M. (2018), 'Union Strategy to Revitalize Weakening Worker Representation in South Korea'. Korea Observer, 49, 1, 83-105.

Knoke, D. and Ishio, Y. (1994), 'Occupational training, unions, and internal labor markets', American Behavioral Scientist, 37, 7, 992-1016.

Kornelakis, A. and Voskeritsian, H. (2018), 'Getting together or breaking apart? Trade union strategies, restructuring and contingent workers in Southern Europe', Economic and Industrial Democracy, 39, 2, 357-375.

Kwon, H. (2015), 'Changing Industrial Relations and Labor Market Inequality in Post-Crisis Korea'. Development and Society, 44, 3, 465-494.

Kwon, S. (2001), 'Economic crisis and social policy reform in Korea', International Journal of Social Welfare, 10, 2, 97-106.

Kwon, S. and Holliday, I. (2007), 'The Korean Welfare State: A Paradox of Expansion in an Era of Globalisation and Economic Crisis', International Journal of Social Welfare, 16, 242-248.

Lazear, E. P. (1986), 'Salaries and piece rates', Journal of business, 59, 3, 405-431.

Lazear, E. P. (2000), 'The power of incentives', American Economic Review, 90, 2, 410-414. 
Lazear, E. P. (2018), 'Compensation and Incentives in the Workplace', Journal of Economic Perspectives, 32, 3, 195-214.

Lazear, E. P. and Shaw, K. L. (2007), 'Personnel economics: The economist's view of human resources'. Journal of economic perspectives, 21(4), 91-114.

Lee, B. H. and Frenkel, S. J. (2004), 'Divided workers: social relations between contract and regular workers in a Korean auto company', Work, Employment and Society, 18, 507-530.

Lee, B. H., Kim, D. B. and Cho, J. (2005), 'Union effect on the use of non-regular labor in the republic of Korea', The Developing Economies, 43, 4, 425-449.

Lee, C. (2006), 'Labor and Management Relations in Large Enterprises in Korea: Exploring the Puzzle of Confrontational Enterprise-Based Industrial Relations' in C. Lee and S. Kuruvilla (eds.), The Transformation of Industrial Relations in Large-size Enterprises in Korea: Appraisals of Korean Enterprise Unionism, Seoul: Korea Labor Institute, 3-33.

Lee, C. H., Lee, K. and Lee, K. (2002), 'Chaebols, financial liberalization and economic crisis: transformation of quasi-internal organization in Korea'. Asian Economic Journal, 16, 1, $17-35$.

Lee, K. and Shin, H. (2018), 'Varieties of capitalism and East Asia: Long-term evolution, structural change, and the end of East Asian capitalism'. Structural Change and Economic Dynamics, https://doi.org/10.1016/j.strueco.2018.06.006.

Lee, Y. (2006), 'Varieties of labor politics in northeast Asian democracies: political institutions and union activism in Korea and Taiwan'. Asian Survey, 46, 5, 721-740.

Lemieux, T., MacLeod, W. B. and Parent, D. (2009), 'Performance pay and wage inequality'. The Quarterly Journal of Economics, 124, 1, 1-49.

Lindbeck, A. and Snower, D. J. (2001), 'Insiders versus outsiders', Journal of Economic Perspectives, 15, 1, 165-88.

Litwin, A. S. and Phan, P. H. (2013), 'Quality over quantity: Reexamining the link between entrepreneurship and job creation', Industrial and Labor Relations Review, 66, 4, 833-873.

MacDuffie, J. P. (1995), 'Human Resource Bundles and Manufacturing Performance: Organizational Logic and Flexible Production Systems in the World Auto Industry', Industrial and Labor Relations Review, 48, 2, 197-221.

Mares, I. (2001), 'Firms and the welfare state: When, why and how does social policy matter to employers?', in P. Hall and D. Soskice (eds.), Varieties of capitalism: The institutional foundations of comparative advantage. New York: Oxford University Press, 184-212.

Martin, C. J. and Swank, D. (2012), The political construction of business interests: Coordination, growth, and equality. Cambridge: Cambridge University Press.

Micco, A. and Pagés, C. (2006), 'The economic effects of employment protection: Evidence from international industry-level data', IZA Discussion Papers 2433, Bonn: Institute for the Study of Labor (IZA).

Millán, A., Millán, J. M., Román, C. and van Stel, A. (2013), 'How does employment protection legislation influence hiring and firing decisions by the smallest firms?', Economics Letters, $121,3,444-448$.

Nijhuis, D. (2009), 'Revisiting the Role of Labor: Worker Solidarity, Employer Opposition, and the Development of Old-Age Pensions in the Netherlands and the United Kingdom'. World Politics, 61, 2, 296-329

OECD. (2007), OECD Economic outlook, 2007/1, Paris: OECD Publishing.

OECD. (2013), OECD Economic outlook, 2013/1, Paris: OECD Publishing.

OECD. (2014), OECD Economic outlook, 2014/1. Paris: OECD Publishing.

Osterman, P. and Burton, M. D. (2004), 'Ports and Ladders: The Nature and Relevance of Internal Labor Markets in a Changing World', in T. Pamela, B., Rosemary (eds.), Oxford Handbook on Work and Organization, Oxford: Oxford University Press, 425-445.

Peetz, D. and Ollett, N. (2006), 'Union growth and reversal in newly industrialised countries: the case of South Korea and peripheral workers', in Wood, G. (ed), Trade unions and democracy: Strategies and perspectives, London and New York: Routledge, 211-240. 
Peng, I. (2012), 'Economic Dualization in Japan and South Korea', in P. Emmenegger, S. Häusermann, B. Palier, and M. Seeleib-Kaiser, M. (eds.), The age of dualization: the changing face of inequality in deindustrializing societies, New York: OUP USA, 226-249.

Piton, C. and Rycx, F. (2019), 'Unemployment Impact of Product and Labor Market Regulation: Evidence from European Countries', IZA Journal of Labor Policy, 9, 1, 1-32. Salvatori, A. (2009), 'What Do Unions Do to Temporary Employment?'. IZA Discussion Paper No. 4554, Bonn: Institute for the Study of Labor (IZA).

Simpson, S., Rorie, M., Alper, M. E., Schell-Busey, N., Laufer, W. and Smith, N. C. (2014), 'Corporate crime deterrence: A systematic review', Campbell systematic reviews, 10, 1, $1-105$.

Swenson, P. A. (2004), 'Varieties of capitalist interests: Power, institutions, and the regulatory welfare state in the United States and Sweden'. Studies in American Political Development, $18,1,1-29$.

Watanabe, H. R. (2018), 'Labour market dualism and diversification in Japan', British journal of industrial relations, 56, 3, 579-602.

Witt, M. A. and Jackson, G. (2016), 'Varieties of capitalism and institutional comparative advantage A test and reinterpretation'. Journal of International Business Studies, 47, 7, $778-806$.

Yoo, G. and Kang, C. (2012), 'The effect of protection of temporary workers on employment levels: evidence from the 2007 reform of South Korea', Industrial and Labor Relations Review, 65, 3, 578-606.

\section{Appendix}

TABLE A1. Descriptive statistics of Variables by Size

\begin{tabular}{llrr}
\hline Categories & Subcategories & Mean & Std. Err. \\
\hline Conversions & Small & 1.80 & 30.26 \\
Exposure & Big & 7.17 & 160.39 \\
& Small & 18.44 & 147.12 \\
Intensity & Big & 84.00 & 1119.00 \\
& Small & 0.13 & 0.68 \\
& Big & 0.07 & 0.34 \\
\hline \multirow{3}{*}{ Characteristics } & & $\%$ & \\
\hline \multirow{2}{*}{ Profit } & Subcategories & (from $=1)$ & Std. Err. \\
& Small & 85.52 & 1.34 \\
Performance Pay & Big & 87.41 & 1.04 \\
\multirow{2}{*}{ Wage } & Small & 43.27 & 1.74 \\
\multirow{2}{*}{ Fringe benefit } & Big & 48.51 & 1.49 \\
\multirow{2}{*}{ Union } & Small & 16.39 & 1.33 \\
& Big & 21.91 & 1.25 \\
& Small & 54.17 & 1.75 \\
& Big & 72.18 & 1.33 \\
& Small & 22.62 & 1.47 \\
& Big & 55.95 & 1.48 \\
\hline
\end{tabular}


TABLE A1. Continued

\begin{tabular}{|c|c|c|c|c|}
\hline Characteristics & & Subcategories & $\begin{array}{l}\% \\
(\text { from }=1)\end{array}$ & Std. Err. \\
\hline \multirow[t]{2}{*}{ Manufacturing } & & \multirow{2}{*}{$\begin{array}{l}\text { Small } \\
\text { Big }\end{array}$} & 29.69 & 1.61 \\
\hline & & & 28.62 & 1.34 \\
\hline \multirow{2}{*}{\multicolumn{2}{|c|}{$\begin{array}{l}\text { Occupational } \\
\text { Diversity }\end{array}$}} & \multirow{2}{*}{$\begin{array}{l}\text { Small } \\
\text { Big }\end{array}$} & 43.85 & 1.75 \\
\hline & & & 45.00 & 1.48 \\
\hline \multicolumn{3}{|l|}{ Characteristics } & $\%$ & Std. Err. \\
\hline \multirow{6}{*}{$\begin{array}{l}\text { Union } \\
\text { Coverage }\end{array}$} & \multirow[t]{3}{*}{ Small } & High coverage & 10.12 & 0.79 \\
\hline & & Low coverage & 12.50 & 0.76 \\
\hline & & No union & 77.38 & 1.03 \\
\hline & \multirow[t]{3}{*}{ Big } & High coverage & 29.21 & 1.06 \\
\hline & & Low coverage & 26.74 & 0.97 \\
\hline & & No union & 44.05 & 1.15 \\
\hline
\end{tabular}

Note: "Small" refers to establishments with less than or equal to 200 employees, while "big" refers to establishments with more than 200 employees. Authors' calculation based on WPS data with longitudinal weights.

Source: Workplace Panel Survey (WPS), 2005-13. 